\title{
Fluid Solidarity among Religious Groups in Situations of Conflict in Dagestan: A Case Study of Confrontation around the Figure of the Village Imam
}

Translation by Tim Beasley

DOI: $10.22394 / 2311-3448-2017-4-1-72-95$

Anna Glyants ${ }^{1}$ - Université libre de Bruxelles (Belgium). Anna. zaytseva@ulb.ac.be

The article is fieldwork based and is devoted to the study of social cohesion in the context of the coexistence of various Muslim communities in a Dagestani village. The article explores social aspects of religious confrontations arising from the forced dismissal of a village imam accused of belonging to the Wahhabist network. The author analyzes narratives surrounding the imam, the central figure of the conflict, as well as the primary line dividing the respective religious communities and the flexibility of the boundaries between various groups/communities. The article concludes by identifying preconditions for the intensification of religious solidarity and its particular normative, cultural, and political dimensions.

Keywords: Dagestan, informal institutions, Muslim communities, religious confrontations, religious solidarity, social constructionism.

SIGNIFICANT portion of political science research concerning
the influence of religion on current political processes in the
republic of Dagestan focuses on the study of armed jihad - its

The Russian version of this article was previously published in: Gosudarstvo, religiia, tserkov'v Rossii i za rubezhom, 2016, 34 (2): 281-309.

This study is conducted as part of the ARC project "Globalization and Militancy in the Muslim World" and is supported by the Université Libre de Bruxelles (ULB), Alice and David Van Buuren Fund and Foundation Jaumotte-Demoulin.

1. The Russian version of the article was published under the authorship of Anna Zaytseva. The present version reflects her current - marital - name, which is Anna Glyants. 
sources, forms, and the possibilities for opposing it. ${ }^{2}$ In my opinion, research into how distinct religious tendencies interact with each other also holds significant potential for understanding the mutual influence of religious and social processes in post-Soviet Dagestan. A multiplicity of Islamic currents is found in this most Islamized republic in Russia, despite the dominance of the Shafi'i school ${ }^{3}$ of Sunni Islam. This diversity is not limited to just the most notable groups, the Sufi brotherhoods (tariqas), ${ }^{4}$ Salafis $^{5}$ and supporters of armed resistance who appeal to religious motives, but represents a mosaic both in religious and ideological terms as well as in terms of the degree of institutionalization in their relationships with the government. 6 With this in mind, it is crucial to understand how in the context of coexistence of different Muslim currents, perceived belonging to one of these religious collectivities influences the formation of religious and extrareligious forms of collective solidarity at the local level. What is the degree of religious collectivity cohesion at the local level under conditions of conflict that public discourse terms "religious"? What organizational features of religious and sociopolitical life can intensify the meaning of religious identification?

2. This refers, first and foremost, to the English-language literature: Campana and Ducol 2014; Campana and Ratelle 2014; Hahn 2008; Ratelle 2013; Shterin and Iarlykapov 2011; Souleimanov 2012; Ware, Kisriev, Patzelt, and Roericht 2002; Emelianova 2015; Ware and Kisriev 2010. For Russian-language political studies on the North Caucasus, see Dobaev 2009; Makarov 2004.

3. A small number of Shi'ites live in southern Dagestan (about 4 percent of believers). The Nogais in North Dagestan follow the Hanafi school of Islamic jurisprudence (Bobrovnikov 2000).

4. Three Sufi tariqas are found in Dagestan: Naqshbandi, Qadiri, and Shadhili. The Dagestani muftiate is dominated by adherents of Sheikh Said Afandi al-Chirkawi, who was killed August 28, 2012. The clannishnness of the Spiritual Board of the Muslims of Dagestan (Dukhovnoe upravlenie musul'man Dagestana, hereafter DUMD), as well as its loyalty to the official power structures, is one of the chief accusations made by its religious detractors.

5. Salafis (from the expression al-salaf al-șālih, pious ancestors) are followers of Sunni Islam. They believe that a return to the lifestyle practiced by the early Muslim community is required, that one should follow the sacred texts and "purify Islam" from many religious rites they consider heretical innovations. Salafism is not a monolithic movement, and this extends to their views on the legitimacy of armed jihad. In recent years the term Salafism has received some notoriety, but the tendency has been to identify it with Wahhabism in spite of essential doctrinal differences and disagreement with this on the part of Salafis themselves.

6. In addition to the different schools and tendencies within the Sufi brotherhoods and Salafist groups, there are other currents present in Dagestan (Hizb ut-Tahrir, Fethullah Gülen's Nurcular movement, etc.). For details, see Ware and Kisriev 2010; Bobrovnikov 2007; Kisriev 2004; Makarov 2004; Iarlykapov 2012. 
The multiethnic lowland settlement of Stalskoe was chosen as a relevant case study. Dissent over the local imam Omaraskhab Alibekov was accompanied by social tension in the public space of the village. The demand for Alibekov's resignation as imam of the central mosque and the reaction of the village residents led to a number of incidents involving collective mobilization within the village and the framing of this conflict as a "religious schism" in the republic and federal press. ${ }^{7}$ It was noted that Sufis live in Stalskoe, but adherents of other Islamic tendencies live there as well, and are identified as either "Salafists" or "Wahhabists," depending on the source. ${ }^{8}$ After the high-profile murder of Imam Alibekov on May 16, 2014, ${ }^{9}$ and other murders in the area in $2014,{ }^{10}$ the situation in Stalskoe was described as resulting from exceptional religious polarization. ${ }^{11}$

7. The attempt was made in Stalskoe in 2007 to force the resignation of Omaraskhab Alibekov, who had held the post of central mosque imam for approximately seven years (author's field notes, henceforth FN), following claims that he was a "Wahhabist." According to some reports, "the basis for this appeal was the actions of DUMD representatives who wanted to replace the current imam Omaraskhab Alibekov with his protégé” (A. Magomedov 2008). In May 2008 Alibekov's opponents sent a written appeal to the government of the republic and the district as well as to the muftiate of Dagestan with a demand to "punish Alibekov." The imam's supporters responded with an open letter in support of Alibekov to the government representatives - the president of the republic, Dagestan's minister of internal affairs, and the head of the district's education department. This did not resolve tension within the community. In August 2013 at Eid al-Fitr (called Uraza Bayram locally, this is the Islamic holiday marking the end of the obligatory fast or uraza during the month of Ramadan) a large-scale fight occurred at the central mosque that required intervention by local law enforcement. A group of armed people attempted to assault Imam Alibekov in the mosque itself, but parishioners succeeded in preventing this.

8. "Wahhabis" (or "Wahhabists") as a term is usually used in the republic to refer to adherents of very different religious schools of Islam who declare themselves distinct from Sufism and do not acknowledge hierarchical submission to the DUMD. This corresponds neither to the meaning of this term in religious studies nor how believers self-designate. The term is often used in public discourse with a negative connotation to mark those who engage in religiously motivated violent acts.

9. On May 15, 2014, the imam left by car for Kiziliurt. The burned-out car with Alibekov's body was found in Buinaksky District twenty-four hours after last contact with him.

10. Several violent deaths occurred in Stalskoe in 2014. Some received special attention. Less than a month after Imam Alibekov's murder, on April 26, 2014, Gadzhi Gasanguseinov, the former chair of the Stalskoe agricultural cooperative (SPK "Ulubiia Buinakskogo") was killed. Another Stalskoe resident, the village deputy Azizov, was killed in July 2014. In addition, in January 2014 the village was sealed off by law enforcement authorities in order to conduct "special measures" in the search for members of illegal armed groups.

11. Press mention of "the Wahhabist mosque" in Stalskoe first appeared after the murder of the former collective agricultural coop chair Gadzhi Gasanguseinov. The press gave various interpretations of the religious position of the imam and his supporters. However, after May 2014 mention of a connection between Alibekov and the militant Caucasian Emirate leader Aliaskhab Kebekov became more frequent. 
Thus, Stalskoe allows an analysis of the degree of solidarity in collectivities designated as religiously opposed groups (Alibekov's supporters and opponents). This can be done by deconstructing concepts based on groupism, "the tendency to take discrete, bounded groups as basic constituents of social life, chief protagonists of social conflict, and fundamental units of social analysis" (Brubaker 2004, 164).

To be clear, I will not try to explicate the reasons for and mechanisms of the conflict's escalation leading to Imam Alibekov's death, or to untangle the conflicting views on the imam's religious position. In studying the interplay of societal and religious processes, I will be focusing on the following: Did the events in Stalskoe, characterized as a religious schism, lead to the crystallization of religious collectivities among the village's residents (Brubaker's so-called "groupism")? Which features of religious and collective life explain the manifestations of religious solidarity in the village? The study of these questions seems promising from the point of view of the sociology of Islam, as well as in examining the dynamic character of the processes of social identification, consolidation, and disintegration.

This article will attempt to clarify these questions through the prism of social constructionism. ${ }^{12}$ It identifies narratives from Alibekov's supporters and opponents as well as organizational aspects of religious division. In addition, after noting the flexibility of religious-group boundaries, it analyzes the structural and situational preconditions (in the normative-religious and social-political dimensions) that facilitate the active and diverse manifestations of religious solidarity in the public space.

\section{Empirical Framework: Situational Analysis of a Lowland Dagestani Village}

The need to account for the causes and development of the conflict, as well as for the peculiarities of social order 13 in this case, justifies

On July 3, 2015, a counterterror operation in Kiziliurtovsky District killed two militants, allegedly members of illegal armed groups. According to the national anti-terror committee, they were implicated in the murders of Osmaraskhab Alibekov and of a madrassa teacher from the neighboring village of Nechaevka in 2014.

12. The goal of this approach is to clarify the collective ideas and processes that influence the formation of collective beliefs. Among its basic postulates is the understanding of knowledge as a social construct, the affirmation of the key role of interaction between individuals in the formation of their perception of social reality, and also stressing variability as one of the meaningful traits of social reality. See Berger and Luckmann 1966; Denzin and Lincoln 2005; Hay 2016.

13. The diversity seen in the social and political legacy of Dagestan is explained not only by the ethnic variety of this most multiethnic of Russia's regions, but also by a series of 
empirical analysis at the micro-level. Moreover, due to a structural feature of Islam (the absence of a clear hierarchy for Muslim clergy and of an institutionally fixed structure for membership in a community of believers) territorial belonging is often a structuring element for organizing a religious community's life in Dagestan. The study of social aspects of religious life in the context of an isolated village allows examination of how Muslims interact within a single religious collectivity, the village jama'at. ${ }^{14}$ A similar analysis in an urban setting would be much more problematic. ${ }^{15}$

To assist in understanding the characteristics of this particular example I will include a brief description of the village of Stalskoe and indicate the empirical basis underpinning the subsequent analytical sections of the article.

\section{Short Description of Stalskoe and Investigative Methodology}

The settlement of Stalskoe is in the Kiziliurtovsky District, forty-five kilometers from Makhachkala. It is a lowland village, founded by immigrants from different districts in the republic. The first settled area here, called Samurkent, formed in the 1920s after construction of the October Revolution Canal. In 1937 it was renamed Stalskii. The village population was composed of several waves of immigrants. The first to arrive were Lezgins and Kumyks, as well as some Germans. ${ }^{16}$ In 1957 Avars from Chechnya's Andalalsky District arrived, who were originally from Ratlub in Shamil'sky District. Avars from the Kvarel'sky District of Georgia (originally from the village of Hunzib, Tsuntinsky District) arrived in two waves - in 1968 and in the early 1990s. People from other parts of the republic are also found in Stalskoe - from the villages of Gimry, Irganai, Arakani (Tsuntinsky District), but also from Keleb in Shamil'sky District, who form their own whole microdistrict

other features rooted in the distinct historical trajectories of dozens of independent communities that have existed in Dagestan since the late Middle Ages, each with different government and political structures ("free communities," khanates, feudal structures). It is also explained by specialization in various types of economic activity, given the wide range of geographic and climatic conditions (Karpov and Kapustina 2011).

14. In this case jama'at is taken to mean the collectivity of believers in the village. This concept has many interpretations and often signifies the collectivity of believers attending a single mosque.

15. The methods employed in the sociology of religion, studying religious life in terms of the sociology of organizations, are not relevant for the study of institutionally "unorganized" Muslim communities. See Jeldtoft and Nielsen 2011; Jeldtoft 2011; Kühle 2011.

16. In 1941 all inhabitants of German origin were exiled from Dagestan. 
in Stalskoe. The village's population has increased over the last decades and today forms a rather lively mosaic. As reported by the informants, the largest groups among the local inhabitants are from the population centers Ratlub and Keleb, or are Kumyks. Informants often repeated that "we're all from someplace else" and underscored Stalskoe's multiethnic composition. "They call our village Dagestan in miniature."17

By Dagestani standards Stalskoe is a large village, composed of several auls. ${ }^{18}$ Many live in Stalskoe but work elsewhere. Men travel for work to Makhachkala or Kiziliurt, taking construction jobs, or working as truck drivers (throughout Russia). Women raise fruit (strawberries, cherries) for sale on the federal "Caucasus" highway that the village is situated on. Cooperative gardens were gradually reduced with the distribution of land, and local agriculture now includes livestock, which provides work for a small number of people. There are four schools in the village, two medical clinics and six mosques (one of which is a "central mosque" or jum'a mosque, where Friday prayers are held, while the rest are for daily prayers).

The scope of my field data consists of interviews with Stalskoe inhabitants, mass media publications (local and federal news sites, Internet portals focusing on Islam), publically available video recordings of Omaraskhab Alibekov, interviews with Dagestani journalists and Muslim activists, as well as field observations made during trips to the village. The theoretical sampling was developed within the framework of Grounded Theory.

Semi-structured interviews ${ }^{19}$ were conducted to clarify religious differentiation of village residents. In pursuing this goal I analyzed

17. FN. FN are the author's field materials collected during field visits to Stalskoe and Makhachkala in April, May, and September 2015.

18. Estimates of the village's population vary by source. According to the 2010 All-Russian Population Census, it stands at 5,729; according to the village administration's webpage it is 9,785 (http://selo-stalskoe.ru/nashe-poselenie-istorija-sela-stalskoe.html). Inhabitants and journalists give figures significantly higher than official sources. (An aul is a Caucasian mountain or desert settlement. - Ed.)

19. Semi-structured interviews were conducted with thirteen local residents, either alone or with two informants present. In the case of certain informants several interviews were held. In most instances the author arranged to speak with the informant directly in their place of business. Sometimes information was garnered indirectly. Considerable material of interest was obtained from informal interactions with local residents during visits to the village, while walking around the village and during short stays with local residents (at the end of April and the beginning of May, as well as in September 2015). Conversations with the informants went beyond discussion of topics connected with the murdered imam. This was partially due to the fact that the results described in this 
their views regarding a concrete example, that is their perception of the imam's belonging to this or that religious tendency. ${ }^{20} \mathrm{I}$ attempted to learn several things from the informants. How did those who supported the calls for Alibekov's resignation identify him, as opposed to those who considered such calls to be groundless? What did informants base their opinion on when it came to applying such labels? It was important to sound out the opinion of as wide a circle of people as possible, so interviews were conducted with a variety of people in religious and social life. These included members of the clergy, administrative and public-sector employees, and local law enforcement. These data were compared with the evidence from diverse sources such as publications specializing in Islamic topics, the study of religion, or the geographic area in question.

\section{"Fluid" Identification of Religious Belonging: Duality of Narratives and Religious Practices}

Was Omaraskhab Alibekov a figure who divided the jama'at into two communities? Did the local residents consider him an adherent of "Wahhabism," as conveyed in some press reports starting in 2014?

At the start of the conflict Omaraskhab Alibekov, originally from the village of Teletl in Shamil'sky District, had been imam in Stalskoe for seven or eight years. Estimates of the number of his supporters and opponents were very inconsistent in both the informants' responses as well as in external sources. The version according to which the group set against him was initially relatively small, thirty to fifty people, is most likely to be true. By 2014 the number of those dissatisfied with him had increased. A portion stopped attending the jum'a mosque and on

article form part of a dissertation project concerning social features of the organization of religious life in contemporary Dagestan. Four expert interviews with residents from other villages were conducted in Makhachkala in spring 2015. All interviews were conducted in Russian.

20. One limitation on sampling was the complexity of identifying and obtaining access to informants who not only supported the deceased imam but were in his inner circle. Not only was the period in which information was gathered relatively short, but it was problematic to obtain access less than a year after the widely reported murder. A second methodological limitation was the impossibility of personally conducting observations in the mosques: it was not appropriate for women to visit the mosque during Friday prayers. This circumstance, as well as a lack of knowledge of the local languages on the part of the researcher, dictated field material collection by means of semi-formal interviews. The author hopes to extend her observations and conclusions based upon more comprehensive empirical materials concerning the daily life of the village's believers. 
Fridays went to the jum'a namaz (Friday prayers) ${ }^{21}$ in nearby villages (Nechaevka and others). Meanwhile, the "more radicalized portion of the Salafists" went to Friday prayers in the neighboring village of Komsomolskoe. ${ }^{22}$ In fact, the village jama'at, that is, the entire body of believers of the individual territorial unit, was organizationally divided. Did this signify the presence of irreconcilably divergent ideological and doctrinal views with correspondingly divergent practices among the village faithful?

To answer these questions I will analyze narratives containing an evaluation of the central figure in the conflict and attempt to ascertain the ideological position of the imam and his supporters.

\section{Duality of Narratives concerning Alibekov}

Based on my material, I can fairly confidently state that Omaraskhab Alibekov neither subscribed to a hierarchical submission to the DUMD (Dukhovnoe upravlenie musul'man Dagestana or the Spiritual Board of the Muslims of Dagestan) nor allied himself with the Sufis or the Salafists. It is important to remember the diversity of religious currents among Dagestan's Muslims: not all Sufis submitted to the DUMD, nor was the Salafist element monolithic. To this day the latter are composed of three or four distinct groups which differ, among other things, in how they view the use of violence. ${ }^{23}$ Alibekov had his own critical viewpoint on a range of topics but did not present his religious perspective in an antagonistic way. ${ }^{24}$ This fact surfaces in the duality of the narratives that characterize how the village inhabitants perceived him.

Informants critical of Alibekov claimed he had an incorrect attitude toward the mufti:

[Alibekov] did not rise to his feet at the entry of the mufti, when he came to the village. He said that "in Allah's house you should rise only before the Most High.”

21. Friday namaz (jum'a namaz) is often called ruzman (from the Avar ruzman - "Friday").

22. FN. Some information indicates this occurred while Alibekov was still alive, not just after his death (after a new imam was appointed by the DUMD).

23. FN.

24. It was known that Alibekov openly criticized instances of torture and the overall situation in the republic, however after he received some warnings he stopped publicly raising these issues $(\mathrm{FN})$. 
Some reports also expressed certainty that "men from the forest" 25 came to see the dibir. ${ }^{26}$ As a rule, they also underscore the dual nature of the information:

People came to see him [Alibekov]. They say he gave them moral instruction regarding law enforcement personnel, that is, to kill them. I asked him about this personally and he told me that this never happened.

If none of the informants actually stated that Alibekov followed false religious teachings, in their opinion, still some were alarmed by the religious practices not of the imam himself but of a group of believers who visited the central mosque:27

From the students you can tell what he [Alibekov] told them. The students preached openly. They call praising the Prophet bid'ah [innovation]. It is forbidden to distribute the șadaqa [charity]. You must not distribute it for the dead. [...] So what was he, a bad teacher or a hypocrite?

Why couldn't they remove Omaraskhab? He showed his good side from the very start. Right up to the end. But he said one thing and did another.

It is difficult to say what percentage of the villagers' views is based on actual interactions or observations. The statement that "they [the group of critical believers] don't say this openly, but only among themselves" was quite a common opinion. As the informants themselves acknowledged, their judgments were often based on others' opinions and they found confirmation when, for example, Alibekov was seen standing next to a "Wahhabist" in Kiziliurt. The man who saw this scene began to spread the corresponding judgment about the imam (FN). Many informants questioned how trustworthy such information was: "So somebody said something. One person said it and so another said it. They hear with their ears but don't see with their eyes." This illustrates how stereotyped views were often spread, namely without being based on direct, real observation, but formed under the influence of collective representations.

25. "From the forest" is an emic expression from FN. This is how members of the armed underground are described.

26. The dibir is the central mosque's imam.

27. The emic terms applied to this group of believers depends upon the religious loyalty of the informant: from "Wahhabists" among DUMD supporters to "those from the jama'at" (jama'at'skie) among Alibekov supporters. 
Those informants who did not think Alibekov was a "Wahhabist" typically included atheists, not just believers. Those believers who supported Alibekov quite often did not self-identity with any specific group or tendency. Instead, they stressed that they had learned their Muslim practices from their parents. Both groups emphasized the "staged" nature of the rumors spread about the imam.

Some informants were aware that the imam received his training in Syria but had been sent to Stalskoe by the Spiritual Board: "As a young man [Alibekov] was sent to Syria. They found he straddled two strains of thought. He knows both tendencies." This two-fold position alarmed those believers who considered submission to the DUMD necessary for religious life.

In general I found no direct confirmation that Alibekov was an adherent of religiously motivated violence. In the words of one female informant, the late imam said that if somebody in his presence called him a "Wahhabist" and demanded that he resign he was willing to comply, "but that nobody had dared take such a sin upon their soul" (FN). It is worth noting that before Alibekov's arrival, at the beginning of the 2000s, the Stalskoe central mosque's imam (named Muhammad) was "removed" because of his "Wahhabist views" when the council of elders reached consensus in calling for his resignation. ${ }^{28}$ However, even those dissatisfied with Alibekov would not allow themselves to speak about the imam in such categorical terms. After Alibekov's death those informants who had criticized his ideological position spoke of him in positive terms, acknowledging his charisma and popularity among the villagers. As one informant said, "When they killed him [Alibekov], the local men cried."29

Overall, the narratives concerning Alibekov show not so much the existence of incompatible attitudinal norms as the presence in the village of many "doubters." In fact, many informants, regardless of their degree of support for Alibekov, stressed that a significant number of the village's believers had no pronounced personal opinion concerning the course of the conflict. For example, supporters of the DUMD, who considered the criticism of Alibekov to be well founded, described the fight at Uraza Bayram (Eid al-Fitr) in August 2013 in the following way:

28. FN. Unfortunately I was not able to obtain sufficiently detailed information about this incident.

29. This comment belonged to one of the representatives of law enforcement who thought that "forest men" paid visits to Alibekov. 
Most were just ordinary people. They saw their leaders fighting. They didn't understand, they just followed along because he was in front of them. Now they follow the new imam. A lot are just indifferent, but they forget about their children.

In fact the relationship of the village faithful and the new dibir sent to Stalskoe by the DUMD in May 2014 has gone fairly smoothly. There were those, however, who changed their attitude toward Alibekov in a positive way (FN).

\section{Disputed Practices}

That Alibekov and his adherents hardly identified themselves as "Wahhabists" can be seen in certain rituals performed by the imam.

Funeral rituals were one reason for the earliest dissent in Stalskoe. These are a known point of division among adherents of Sufi versus Salafist tendencies. Not all inhabitants of the area agreed with Alibekov's criticism of certain traditions. In the words of an informant who numbered himself among Omaraskhab's supporters, one cause of dissatisfaction was Alibekov's negative opinion of women's dhikr for the dead as well as visiting the graveyard on Friday. ${ }^{30}$ Nonetheless, all relatives and those close to the deceased, regardless of their ideological differences over rituals, attended village funerals. Burials at the Stalskoe graveyard were not marked by divisions based on religious tradition, as often happens in villages with clearly pronounced religious confrontation.

In addition, video recordings show Alibekov's participation in practices criticized in Salafist circles. Alibekov is seen in a video recording from 2011 participating in a mawlid (a celebration of the Prophet's birthday) in Kaspiysk on February 18, 2011 (Mawlid video 2011, Mawlid video 2013). This practice is condemned in Salafist circles as bid'ah, innovation. ${ }^{31}$ Moreover, the outward appearance of those attending the mawlid (green skullcaps) seems to indicate that there were numerous other supporters of the Sufi religious leader Said-Afandi al-Chirkawi in the mosque with Alibekov.

30. In the informant's words, the imam stressed that the rite should not be for show. (Dhikr is prayer involving the names or attributes of Allah. - Ed.)

31. That mawlids are permitted if not connected with the assumed date of the Prophet Muhammed's birth finds no dispute among the different currents of Islamic thought. 
Many informants repeatedly stressed that Alibekov had a meek, non-confrontational nature and lacked any principled position on a number of religious questions. In part, it was noted that this was why certain of the "harsher" Salafists criticized him. According to one informant who belonged to Salafist circles and who was well informed concerning events in the village, Stalskoe's population was not so religious that ideological debate would lead to real polarization (FN).

Overall the "flexible religious boundaries" as described by V. O. Bobrovnikov apply to the situation in Stalskoe: "With the exception of individual intolerant leaders who preach 'the purification of Islam' from Wahhabists or from Sufis, most of the jama'at changes its religious orientation on an ad hoc basis, now joining one faction, now another" (Bobrovnikov 2012).

Dissatisfaction with Imam Alibekov found expression in the fragmentation of Stalskoe's religious life and a division of the residents during jum'a prayer. This one fact, however, does not allow us to draw the conclusion that the collective identity of the faithful crystallized in a way that clearly led to the formation of two distinct religious groups holding irreconcilable ideological and doctrinal attitudes. A significant portion of the population characteristically had no clear position on the imam, contrary to the external view ("framing") of the situation as a religious schism.

\section{The Normative-Religious and Situational-Political Premises of Religious Solidarity Manifestations in the Public Sphere}

I will now analyze the organizing features of religious and collective life in which the perception of a dibir's religious belonging may trigger processes of religious identification at the village level.

\section{The Question of the Efficacy of Religious Rituals}

Above all, the value of the central mosque's imam is to be found in the religious rites that he participates in. Recall that the imam's status was repeatedly contested by a particular portion of the jama'at through their refusal to participate in the collective festive Friday prayer led by Alibekov. Yet, in contrast to afternoon prayer, Friday (noon) prayers must be performed as a collective, by the entire community, in the area's "cathedral" (central) mosque. An exception is permitted only when it is overcrowded. The efficacy of the jum'a prayers is seen as requiring a quorum of celebrants in the mosque. This might be from 
three to forty men, depending on the scholar's legal opinion. These men must have mastered makhraj (the ability to properly pronounce the sounds and recite the prayer). In Stalskoe, after the unsuccessful attempt to remove Alibekov, part of the faithful conducted Friday prayers in a new mosque:

The mufti refused to explain the reasons for his actions, and his supporters afterward opened a new mosque in the village. Among other things, they held Friday prayers there, which is considered a significant violation of Islamic law (Administrative District in Dagestan 2008).

For both the faithful who supported Alibekov, as well as for those who advocated his "resignation," the collective performance of the Friday prayers under the leadership of the imam they supported became an important factor in self-identification and affirmation of their religious solidarity in the public space.

In addition to Friday prayer, criticism of the religious affiliation of the imam was directly tied to the perceived efficacy of important collective life-cycle rituals he performed (weddings, burials, etc.). ${ }^{32}$ Some information indicates it was the mufti of Dagestan himself who characterized all religious acts by Alibekov as unlawful (Magomedov 2008). ${ }^{33}$ For those who believed that the imam followed faulty religious laws, the rituals that he performed were of no effect. ${ }^{34}$ This weakened the integrating and regulatory function of rituals and rites at the level of village society, which, in turn, triggered a need to affirm anew religious identification at the village level.

\section{The Source of the Imam's Legitimacy: The Jama'at or the DUMD?}

The conflict was also motivated by the presence of diverging interpretations of the question of appointing the imam. At the heart of the competing ideas on this matter in Dagestan lie differing attitudes

32. I note that life-cycle rituals in Dagestan have a sharply pronounced mass character. A wedding or "expressing condolences" for a single family will draw, as a rule, hundreds of people.

33. However, the mufti himself denied that he forbade praying for Alibekov.

34. From the point of view of Islamic scholars, even if there are certain religious differences the proof that a ritual's performance is "unlawful" cannot be established without serious theological analysis. From the layman's point of view differences in religious practices are often perceived in more absolute terms (FN). 
concerning the administrative leadership that the DUMD has over other Muslim organizations.

The first view acknowledges that the DUMD legitimately appoints the imam:

The procedure for appointing the imam occurs with the consent of the highest authority, which is the DUMD. Mufti Ahmad-Haji Abdulaev presides over it; he's elected by the ulema and the imams of the Dagestani Republic. Sharia law and generally accepted principles dictate that one must submit to him. The DUMD and the mufti either appoint the imam themselves, or they nominate a candidate and then confirm him later. But if the jama'at has a candidate, they have the right to request his confirmation. [. . .] The clergy can also propose their own candidate, but cannot in any case force him on the jama'at. Everything is done by consent and it is a joint decision. ${ }^{35}$

This is not a view universally held by those who perceive the DUMD's decisions as a manifestation of "appointment politics" by the "official" clergy, an attempt to enhance the position of those who follow Sheikh Said al-Chirkawi (see A. Magomedov 2008; M. Magomedov 2008). Thus, at the start of the conflict in Stalskoe a rather large portion of the villagers called for Alibekov's stay:

The local population, dissatisfied that the imam of the village mosque could be replaced without their concurrence, registered their protest. A petition was addressed to the republic's authorities with approximately 700 signatures in support of Alibekov. A certain person influential in the Dagestani Republic (head of one of the district administrations) even spoke with Mufti Abdulaev (M. Magomedov 2008).

The importance of the village residents' collective decision as the chief factor conferring legitimacy on a cleric in the post of dibir stands out:

Indignant parishioners declared that they hired the imam and that he suits them well - and that if he had to be removed from the position they would decide the matter without any outside interference. They asked the mufti to state his case in public (Administrative District in Dagestan 2008).

35. From an interview with the imam of the Makhachkala central jum'a mosque Mukhammadrasulom-khadzhi Saaduev (A. Magomedov 2008). 
The dominant role the DUMD plays in the religious life of the presentday republic is not supported by the institutionally fixed mechanisms and practices for appointing an imam. The DUMD argued for the expediency of Alibekov's departure in the following way:

Gadzhiev36 also explained that the Dagestani mufti Akhmadkhadzhi Abdullaev personally stated during a conversation that he had never gone on record concerning Alibekov's removal from his post. "I prayed behind him at the time, so how can I say that it was forbidden for others to pray for him? The villagers were divided in two over Alibekov, so it was suggested that he leave his post because he couldn't unify them all" (Administrative District in Dagestan 2008).

It was still worthwhile for the imam to secure the support of the community or the most important of its representatives. One would imagine that the reverse would also be true, that in order to remove the imam from the post it would be necessary to apply pressure on the jama'at and/or important players in society. In the 2000 similar disagreements led to conflicts not just in Stalskoe, but also in other locations in Dagestan of different sizes, and with different ethnic compositions and types of social organization (for example, in the city of Derbent, the populated mountain area of Sogratl, the lowland area of Komsomolskoe, and even the conflict in Makhachkala in November 2015).

And so the conflict that broke out in Stalskoe was, among other things, motivated by the presence of different attitudes concerning the role of believers in the formation of the institution of the central mosque imam, as well as by the role of the DUMD as an institution claiming to be the highest religious authority. The conflict's duration was related to the absence of a consensus and an effective mechanism to resolve such a situation.

\section{The Role of the Imam in the Public Life of the Local Society}

Finally, disagreements over the role of the dibir can become a trigger for collective mobilization when he is included in the various processes involving resource distribution and the maintenance of social status in the village. What were the relevant social, religious and cultural practices? 
Important village affairs are usually discussed on Friday after collective prayer. Any matter could be raised in the presence of the jama'at, including who would be the best candidate in elections. As far as the choice of topic for discussion or the Friday sermon (khutba) itself, if the imam had been appointed by the DUMD the agenda might partially be set based on its recommendations (FN). Regardless of the religious loyalty of the imam and his position vis-à-vis the DUMD, the imam often directed the khutba topic toward a discussion of specific socially meaningful incidents that had occurred in the village (FN). The degree of politicization of the topics, the influence that the imam had on the jama'at and his interference in secular matters varied greatly by context, and the factors determining the imam's authority (his age, degree of familiarity with village problems and methods of solving them) (Kapustina 2012; Karpov and Kapustina 2011). When the conflict arose Alibekov had been village imam in Stalskoe for about seven years, however his age (under 40) and origin (not a Stalskoe native) did not garner him great authority. Nonetheless, according to one informant, he was very charismatic and, although he could afford to be critical, was generally noted for his peaceable nature.

Another instance accentuating the imam's importance was his inclusion in the informal institutions that governed the village's social life. In Stalskoe, the imam is invited to formal and informal collective meetings in which the residents participate. For example, each quarter there are three or four meetings of the village council at which most of the jama'at members gather. Important announcements are made at the village councils and villager misconduct might be discussed. The village deputies invite the imam to their meetings, as does the council of elders. ${ }^{37}$ It follows that the central mosque imam plays an important role not only in religion but also in the life of the village as a whole.

How significant is the imam's authority and how is it balanced with other local authorities? In the final analysis the imam's influence on social processes depends on a complicated set of factors - upon the distribution of social roles among local influential players. In the event of religious dissent in the community the imam can decide to abdicate his post in order to avoid escalating the conflict and causing a village

37. About five men from different tukhums (family-clan groups) are in the Stalskoe council of elders: "mature men that know everything, who have worked and are active in labor" (FN). While gathering field material (May through September 2015) the council consisted of three men (the other two had recently passed away) and was awaiting local elections to fill its ranks in September 2015. 
schism. ${ }^{38}$ If the people with authority in the village, however, support the imam, he can remain even with continuing dissent. ${ }^{39}$ This is not so much a question of the imam's ratio of supporters to detractors as of the authority of certain actors and whether they support or oppose him.

In Alibekov's case, the imam still enjoyed the support of the "elders," although according to some accounts, over time their relations became somewhat tense. As noted above, the previous dibir Muhammad was "ousted" as a result of his "Wahhabist views" precisely because of the consolidated position of the council of elders. 40 However, in the following years people listened to the elders less than before, with those who had achieved material success holding most authority. From field notes and the press it is known that certain "situational authorities" (influential people) in Stalskoe were set against the imam. However, according to one of the female informants, in 2013 the elders supported Alibekov and did not trust the repeated rumors. "We know our imam" (FN). Nonetheless, to understand the balance of power, another characteristic of the elders must be pointed out: "They may decide little, but they know a lot" (FN). Overall, the opinion was that those with administrative resources had excessive leverage over complicated situations like the one in Stalskoe. It is apparent that compared to the 1990 s the role of the traditional institution of elders had weakened.

It is also important to clarify the features of Stalskoe's social structure as a multiethnic lowland village. Stalskoe has less community solidarity than highland settlements and villages with more homogeneous populations. This explains the reduced authority of informal traditional institutions and/or the existence of a more complicated means of balancing the interests of diverse groups. ${ }^{41}$ One informant's comment concerning a neighboring village in

38. FN. According to press accounts, Alibekov offered to abandon his post on his own initiative, if the faithful could find a compromise figure that they could agree on.

39. Informants included among their number some of those who enjoyed respect in the village either due to age and knowledge or because of their economic and/or administrative resources.

40. The situation here pertains mostly to the early 2000 s.

41. My hypothesis concerning this situation is this. Traditional institutions more quickly lose their power in lowland immigrant villages because it is more difficult to preserve the elders' influence when the village's composition is much more diverse, with a greater number of tukhums. At the same time, they are relatively close to towns, which somewhat augments the tendency toward individualized life strategies and the possibility of forming other, situational, authority types. 
Kiziliurtovsky District, Kirovaul, is telling: “They don't have this kind of mess there. They're all from Tsumandinsky, from the same district. We have a multiethnic village here." A competitor in terms of group solidarity might not be a person from another ethnicity as much as a person who comes from a different district. For Stalskoe residents, the place of origin is as important as ethnic origin in how the village is divided.

So the dibir acts as a significant contributor to the informal regulation of social processes. This, in turn, increases the merit of appointing a consensus figure to that post. At present many lowland villages have a multi-leveled system of loyalty, and the means of resolving controversial issues through traditional representative organs (the council of elders) is undergoing change.

Below it becomes clear that the public display in Stalskoe of religious solidarity in particular was possible due to specific situations involving conflict.

\section{Situational-Political Context}

First, an important source of conflict is the general process of securitizing religious issues. ${ }^{42}$ This refers to the elevation of religious belonging to the rank of a security problem in the context of the long-term struggle on part of Russian authorities against an armed underground, coupled with a recent rallying of its members to the side of the so-called Islamic State (IS). The latter has been acknowledged by the Supreme Court of the Russian Federation to be a terrorist organization. In the Kiziliurtovsky District counterterrorist operations (CTO) have been carried out repeatedly in recent years, and the "Kiziliurtovsky band" is considered one of the most active organizations of this extremist underground (Rybina 2015). Operations to neutralize militants have been repeatedly conducted in and around Stalskoe.

Together with ongoing CTOs in the republic, increased monitoring of those who follow Salafism has been accompanied with numerous human rights violations (Human Rights Watch 2015). Against this backdrop, a subset of the faithful find it especially problematic to have any affiliation with a religious community not declaring loyalty to the DUMD. This is due to the Russian authorities' practice of "too broad

42. The concept of "securitization" was developed by the Copenhagen School for the field of international security. For more details see Buzan, Waever, and de Wilde 1998. 
an approach" when Salafists are suspected of religious extremism. The discourse formed in the public space against religious "members of the opposition" and their actual equivalence with Wahhabists and militants in certain instances simplifies a partition into "us" and "them," thereby intensifying the religious divide. By contrast, many village residents are distrustful of the official interpretation of events (for example, the official version of Alibekov's murder by militants who were members of the "Kiziliurtovsky band"). One way or another, the scale, form and length of the struggle with the armed underground sets the tone for societal life and enables a more active manifestation of religious solidarity in the public space.

Secondly, the imam's authority can serve as capital in the battle for resources that constitute influence. Omaraskhab Alibekov's critics included influential village residents. It is extremely likely that at first there was just a small group of people actively opposing Alibekov, ${ }^{43}$ who were supported by influential people at the local level as well as by religious authorities outside of the village who supported the DUMD's line. This group's actions produced or deepened already existing religious disputes in the village. A similar view is expressed in an article about Stalskoe published in the social-political weekly Molodezh' Dagestana (Youth of Dagestan) from December 6, 2013:

There are virtually no grounds for interethnic or intrareligious conflicts [in Stalskoe], but from time to time friction is artificially created (by ambition or out of a thirst for power by those who desire some office or another).

Some information indicates that the "active propaganda campaign to remove the imam of the local mosque, O. Alibekov" was staged with the support of people who at one time enjoyed access to the village's administrative resources (Moscow Helsinki Group 2009). Information published in the republic newspaper Chernovik leads to the conclusion that the inability of the jama'at and imam to come to an agreement thwarted the political ambitions of some authority figures at the local level (who, in turn, denied such an interpretation) (for details, see Akhmedov 2013). It is important for my analysis to note that a certain portion of the village inhabitants held the conviction not only that Alibekov had influential opponents but that these opponents actively worked to "discredit the local imam"

43. Some sources indicate this group was dominated by people from Ratlub. 
(Akhmedov 2013). The informants judged these types of activities to be provocations, serving only to intensify the division between supporters and opponents.

Finally, I must mention land, one of the most important sources of conflict in contemporary Dagestan (Adiev 2010, 153; Kazenin 2012; Kazenin 2015; Starodubrovskaia et al. 2011). The distribution of land parcels has in recent years become an important issue in Stalskoe. "In the last year [2014] they dispensed more than 2000 land parcels because the population increased" (FN). I do not have detailed information on this process, nor on Alibekov's position on the land question or his participation (or lack thereof) in resolving land issues. This topic merits separate investigation and lies beyond the scope of this article. Nonetheless, I think it important to point out this possible nexus of interests leading to conflict. The imam's authority and his membership in one particular religious community might be perceived as yet another, additional social resource for advancing their own interests. Judging by the press publications and the field material I gathered, a solution to the land question in this case, as in many large lowland Dagestani villages, is quite complicated. Among the reasons for this complexity is a lack of congruence in the interests of individual players. ${ }^{44}$

\section{Conclusion}

An analysis of the situation in Stalskoe revealed several features in the structuring of religious life when different Muslim currents coexist. Further, it allows an investigation of how these are connected with local conflicts.

The first conclusion paradoxically involves specifying the nature of the religious schism during conflict in the religious sphere (at the microlevel) and against the background of the securitization of religious belonging (at the macrolevel). In examining the village inhabitants' religious narratives concerning the late imam Alibekov, it became clear that conflict does not necessarily lead to a crystallization of religious identity in an antagonistic way. Religious division might involve an institutional character, reflecting in particular one's attitude to the DUMD, but not necessarily be related to any mutually exclusive

44. In this connection, one cannot overlook the July 27, 2014, murder of a Stalskoe land commission deputy who dealt with parcel distribution in the administration. See "Ob ubiistve deputata” 2014. 
set of starkly pronounced ideological goals and/or religious practices. The active parties to conflict might form a relatively insignificant portion of the group. Meanwhile, a significantly large stratum of the population may have no obvious, pronounced opinion, meaning that it can adopt attitudes in an ad hoc fashion.

Framing the Stalskoe situation as a religious schism, as a confrontation between "Wahhabists" or "Salafists" versus DUMD supporters, does not reflect the multifaceted nature of how religious division arises. This reflects the importance of the deconstruction of religious markers when choosing categories for social analysis, which permits a more precise determination of the actors in a community's religious life and a consideration of the sociological features of Islam (i.e., the absence of a "church" structure, flexibility of cultic and ritual practices). Furthermore, this helps to reveal the real correlates of socio-religious attitudes and a more precise identification of the active actors in socio-political processes.

The second conclusion is that acknowledging the situational nature of religious identification and exposing how the religious authorities (in this case, the imam of the central mosque) are integrated into the distribution of symbolic and material resources indicates more than just the possibility of instrumentalizing religion to further the interests of one player or another. Belonging (individual or collective) to a particular religious tendency within Islam undergoes instrumentalization in the context of modern Dagestan. This is facilitated by official discourse and practices that perpetuate the dichotomy between "traditional" and "Wahhabist" Islam. Categorization of the religious sphere has social significance. For "religious entrepreneurs" this creates an impetus to invent "religious boundaries" (and to control them) - boundaries that counterpose collective identities based on religion.

Further research will include expanding views on mechanisms of religious socialization at the local level as well as identifying different modalities in which believers are involved in particular types of loyalty (e.g., how social roles are distributed in a village relative to division into tukhums, client networks, etc.). Work in these two areas will yield a more precise view of the mechanisms influencing the formation of religious identity. It will further the understanding of the set of informal authorities that determine competing and complementary types of group solidarity at the local level. Lastly, it will foster comprehension of the form and stages of consolidation in Muslim communities. 


\section{References}

Adiev, A. 2010. Zemel'nyi vopros $i$ etnopoliticheskie konflikty $v$ Dagestane [The land question and ethno-political conflicts in Dagestan]. Rostov-on-Don: SKNTs VSh, IuFU.

Administrative District in Dagestan. 2008. "Administratsiia raiona v Dagestane pytaetsia sniat' vnutrireligioznuiu napriazhennost' v selenii Stal'skoe" [The district administration in Dagestan attempts to remove intra-religious tension in the village of Stalskoe]. Kavkazskii uzel, May 30. http://www.m.kavkaz-uzel.ru/articles/ 137154/?full_page=true.

Akhmedov, M. 2013. "Uraza po-stal'skii” [Eid à la Stalskoe]. Chernovik, August 16. http:// chernovik.net/content/novosti/uraza-po-stalski.

Berger, P. L., and T. Luckmann. 1966. The Social Construction of Reality. London: Penguin Books.

Bobrovnikov, V. 2007. “'Islamskoe vozrozhdeniie’ v Dagestane: 20 let spustia” [The Islamic renaissance in Dagestan: Twenty years later]. Tsentral'naia Aziia i Kavkaz 2 (50): 161-72.

Bobrovnikov, V. 2012. "Islam, vlast' i obshchestvo v byvshem kolkhoze: Dagestanskii sluchai” [Islam, power and society in the former kolkhoz: The case of Dagestan]. In Obshchestvo kak ob"ekt i sub"ekt vlasti: Ocherki politicheskoi antropologii Kavkaza [Society as the object and subject of power: Sketches in the political anthropology of the Caucasus], edited by Iu. Karpov, 9-31. Saint-Petersburg: Izdatel'svto peterburgskoe vostokovedenie.

Brubaker, R. 2004. Ethnicity without Groups. Cambridge, MA: Harvard University Press.

Buzan, B., O. Waever, and J. de Wilde. 1998. Security: A New Framework for Analysis. London: Lynne Rienner Publishers.

Campana, A., and B. Ducol. 2015. "Voices of the 'Caucasus Emirate': Mapping and Analyzing North Caucasus Insurgency Websites.” Terrorism and Political Violence 25 (4): 679-700.

Campana, A., and J. F. Ratelle. 2015. "A Political Sociology Approach to the Diffusion of Conflict from Chechnya to Dagestan and Ingushetia." Studies in Conflict and Terrorism 37 (2): 115-34.

Denzin, N. K., and Y. S. Lincon. 2005. The Sage Handbook of Qualitative Research. 3rd ed. Los Angeles, CA: Sage Publications.

Dobaev, I. 2009. Souremennyi terrorizm: Regional'noe izmenenie [Modern terrorism: The regional dimension]. Rostov-on-Don: SKNTs VSh, IuFU.

Emelianova, G. 2015. "Islam, Nationalism and State in the Muslim Caucasus." Caucasus Survey 1 (2): 3-23.

Hahn, G. M. 2008. "The Jihadi Insurgency and the Russian Counterinsurgency in the North Caucausus.” Post-Soviet Affairs 24 (1): 1-39.

Hay, C. 2016. "Social Constructivism.” In Routledge Handbook of Interpretive Political Science, edited by M. Bevir and R. A. W. Rhodes, 99-113. New York: Routledge.

Iarlykapov, A. 2012. “Sovremennyi Dagestan: Aktula'nye etnopoliticheskie i etnokonfessional'nye problem” [Contemporary Dagestan: Current ethnological and ethnoconfessional problems]. NB Problemy politiki i obshchestva 3: 130-53.

Jeldtoft, N. 2011. "Lived Islam: Religious Identity with 'Non-organized' Muslim Minorities." Ethnic and Racial Studies 34 (7): 1134-51. 
Jeldtoft, N., and J. S. Nielsen. 2011. "Introduction: Methods in the Study of 'Non-organized' Muslim Minorities." Ethnic and Racial Studies 34 (7): 1113-19.

Kapustina, E. 2012. "Vybory v sel'skom Dagestane: Politicheskoe sobytie kak element sotsial'noi zhizni" [Elections in rural Dagestan: A political event as an element of social life]. In Obshchesvto kak ob"ekt i sub"ekt vlasti: Ocherki politicheskoi antropologii Kavkaza, edited by Iu. Karpov, 32-6o. Saint Petersburg: Izdatel'stvo peterburgskoe vostokovedenie.

Karpov, Iu., and E. Kapustina. 2011. Gortsy posle gor: Migratsionnye protsessy $v$ Dagestane $v X X$-nachale XXI v.; Ikh sotsial'noe, etnokul'turnye posledstviia i perspektivy [Post-highland highlanders: Migration processes in Dagestan in the twentieth to early twenty-first century; Their social, ethnocultural consequences and prospects]. Saint Petersburg: Peterburgskoe vostokovedenie.

Kazenin, K. 2012. Elementy Kavkaz: Zemlia, vlast', ideologiia $v$ severokavkazskikh respublikakh [Elements of the Caucasus: Land, power, ideology in the North Caucasus republics]. Moscow: Regnum.

Kazenin, K. 2015. "Regulirovanie zemel'nykh otnoshenii v Dagestane: Sotsialnoekonomicheskie korni 'traditsionalizatsii”" [Regulation of land relations in Dagestan: Socio-economic roots of 'traditionalization']. Ekonomicheskaia politika 10 (3): 11333 .

Kisriev, E. F. 2004. Islam i vlast'v Dagestane [Islam and power in Dagestan]. Moscow: OGI.

Kühle, L. 2011. "Excuse Me, Which Radical Organization Are You a Member Of? Reflections on Methods to Study Highly Religious but Non-organized Muslims." Ethnic and Racial Studies 34 (7): 1186-1200.

Magomedov, A. 2008. "Zhiteli selenia Stal'skoe v Dagestane trebuiut ostavit prezhnego imama" [Inhabitants of the village of Stalskoe in Dagestan demand their former imam stay]. Kavkazskii uzel, May 13. http://www.kavkaz-uzel.ru/articles/136333/.

Magomedov, M. 2008. "Rabota nad . . imamami" [Work on . . imams]. Chernovik 23, June 6. http://chernovik.net/content/novosti/rabota-nad-imamami.

Makarov, D. V. 2004. "Radikalizatsiia islama v Dagestane: Vozmozhnosti i predely dzhakhidizma." [Radicalization of Islam in Dagestan: Potential and limits of jihadism.] Obshchestvenny nauki i sovremennost' 6: 147-61.

Mawlid video. 2011. "Mavlid-TIELEK" g. Kaspiiske (07.02.2011 g.). https://www.youtube. com/watch?v=a4OBE5wM_zE.

Mawlid video. 2013. "Umar-Askhab Stal'skii (mavlid)" [Umar-Askhab from Stalskoe (mawlid)]. https://www.youtube.com/watch?v=CUphhTCXUO8.

Moscow Helsinki Group. 2009. Prava cheloveka $v$ Rossiiskoi Federatsii: Sbornik regional'nikh dokladov [Human rights in the Russian Federation: Regional reports]. Vol. 2.

"O[b] ubiistve deputata v dagestanskom sele Stal'skoe." [The murder of a deputy in the Dagestani village of Stalskoe]. 2014. Kavkazpress.ru, September 3. http:// kavkazpress.ru/archives/54204.

Ratelle, J. 2013. "The Insurgency in the North Caucasus: Putting Religious Claims into Context." Russian Analytical Digest 131: 5-8.

Rybina, Iu. 2015. "Boeviki ukryvalis' v blindazhe” [Militants were hiding in the bunker]. Kommersant, July 5. http://www.kommersant.ru/doc/2762261.

Shterin, M., and A. Iarlykapov. 2011. "Reconsidering Radicalisation and Terrorism: The New Muslims Movement in Kabardino-Balkaria and Its Path to Violence." Religion, State and Society 2: 303-25. 
Souleimanov, E. 2012. "Islam, nationalism et vendetta: Linsurrection au Caucase du Nord" [Islam, nationalism, and vendetta: The North Caucasus insurrection]. Politique étrangère 2: 375-86.

Starodubrovskaia, I., N. Zubarevich, D. Sokolov, T. Intigrinova, N. Mironova, Kh. Magomedov. 2011. Severnii Kavkaz: Modernizatsionnyi vyzov [The North Caucasus: The challenge of modernization]. Moscow: RANKHGS.

Ware, R., E. Kisriev, W. Patzelt, and U. Roerich. 2002. "Dagestani Perspectives on Russia and Chechnya." Post-Soviet Affairs 18 (4): 306-31.

Ware, R., and E. Kisriev. 2010. Dagestan: Russian Hegemony and Islamic Resistance in the North Caucasus. Armonk, NY: M. E. Sharpe. 